\title{
A IMUNIDADE TRIBUTÁRIA DO LIVRO ELETRÔNICO ${ }^{1}$
}

\section{Roberto Caldas ${ }^{2}$}

Resumo: $O$ presente artigo, inicialmente, apresenta o problema das dificuldades de compatibilização da imunidade tributária do livro entre suas duas vertentes, quais sejam, a impressa e a eletrônica, como sendo o grande obstáculo a ser superado pelo Direito Constitucional e Tributário. Em seguida, versa sobre os rumos interpretativos atuais da imunidade tributária sobre livros, jornais, periódicos e o papel destinado a sua impressão. $\mathrm{Na}$ sequência, estuda a interpretação relativa especificamente ao livro eletrônico, inclusive à luz da sua jurisprudência, concluindo por seu pleno cabimento.

Palavras-chave: Imunidade tributária. Livro eletrônico. Interpretação.

\section{INTRODUÇÃO}

O presente estudo tem por objeto a imunidade tributária do livro eletrônico, a qual, como quaisquer das outras espécies, é vista enquanto inserta em norma constitucional que co-delineia a competência tributária e, mais especificamente, o poder de tributar, sendo este um tema pátrio por excelência.

1 Parte das idéias aqui desenvolvidas apresentam-se contidas na dissertação de mestrado do autor, sendo aqui revistas e ampliadas [vide Imunidades tributárias. São Paulo, 2002, 144 p., Dissertação (Mestrado em Direito), Faculdade de Direito da Pontifícia Universidade Católica de São Paulo].

2 Mestre e Doutor em Direito Público pela PUC/SP.Professor da PUC/SP.Advogado no Brasil e em Portugal. E-mail: robertocsgcaldas@uol.com.br. 
As imunidades tributárias, como um todo, são tratadas com institutos afins, de Direito Constitucional e Tributário, mediante uma conceituação que permite as ver consubstanciadas em normas jurídicas impregnadas de um modal proibitivo de conduta legiferante a respeito de certas pessoas, matérias ou circunstâncias. Conceitos como de "não-incidência", "exclusão ou exoneração de competência", "limitação constitucional ao poder de tributar”, dentre outros, em regra são tratados, para as críticas pertinentes, quando em relação às imunidades tributárias.

O seu tema, no mais das vezes, também enseja que se estabeleça breve paralelo com as isenções, buscando uma diferenciação mais precisa entre as imunidades tributárias de eficácia contida e as isenções heterônomas ${ }^{3}$, circunstância em que as funções das leis complementares, ao veicularem matéria tributária, são objetivamente diferenciadas.

A par da sua conceituação e dos conceitos fundamentais dos institutos parelhos, é comum partir-se para a análise de suas classificações mais úteis, ou melhor, mais adequadas, consentâneas para com o ordenamento jurídico indígena, de sorte a permitir uma melhor interpretação e identificação das suas várias manifestações constitucionais - cerca de 30 (trinta) delas, número bastante expressivo quando comparado com as Constituições brasileiras passadas.

Essa linha de análise é que autoriza ver-se a tendência do legislador constituinte dela se ter utilizado para alcançar os inte-

3 José Souto Maior Borges a respeito deixa claro que "As isenções pela União de impostos estaduais e municipais constituem espécies de exonerações fiscais que certa feita nomeei "limitações heterônomas de direito interno", visando a distingui-las das isenções outorgadas pela própria pessoa constitucional competente para a instituição dos impostos de que ela mesma isenta. Isenções, essas últimas, que correspondem a autolimitação do poder de tributar, "limitações autônomas" portanto (cf. Isenções Tributárias, $1^{a}$ ed., 1969, p. 227). Suponho que, a partir daí, a dicotomia isenções autônomas/isenções heterônomas fez fortuna na doutrina brasileira..." ["Isenções em tratados internacionais de impostos dos Estados-membros e Municípios". In: LÓPEZ DÍAZ, Antonio et alii. Direito tributário: estudos em homenagem a Geraldo Ataliba. MELLO, Celso Antônio Bandeira de (Org.). São Paulo : Malheiros Editores, 1997, p. 177, $n^{\circ}$ 5.3]. 
resses coletivos que pretendeu ver resguardados da tributação em geral, de modo a implicar, na mesma proporção, uma maior atenção dos seus intérpretes, quando da busca do seu sentido e amplitude.

É consabido que a imunidade tributária, quando genericamente considerada, por ser naturalmente elevada ao mais relevante dos institutos exoneratórios, impondo uma barreira intransponível ao poder de tributar, necessita ser interpretada de modo evoluído, pois só assim adequada para atender aos anseios e necessidades sociais a que se presta.

E esse exercício de interpretação para busca do seu sentido e amplitude é que ora se desenvolve à luz de uma específica circunstância, qual seja, a do livro eletrônico, mediante corte metodológico a tomar como supedâneo, como pressuposto, o conjunto de idéias já estabelecidas em trabalho afim a respeito da hermenêutica constitucional das normas de competência tributária (atributivas e desonerativas) ${ }^{4}$.

\section{CONSIDERAÇÕES EM TORNO DA INTERPRETAÇÃO DA IMUNIDADE TRIBUTÁRIA SOBRE LIVROS, JORNAIS, PERIÓDICOS E O PAPEL DESTINADO A SUA IMPRESSÃO (ART. 150, VI, “D”, DA CONSTITUIÇÃO FEDERAL DE 1988)}

A imunidade tributária a respeito do livro eletrônico e a exegese inclusive sobre a sua existência passam pelo precípuo entendimento da amplitude, extensão da prescrição havida no art. 150, VI, “d”, da Constituição Federal de 1988, ou seja, sobre o que se deve ter por "livros, jornais e periódicos", sem se olvidar da referência feita expressamente ao insumo "papel destinado a sua impressão”.

4 CALDAS, Roberto Correia da Silva Gomes. "Breves considerações em torno da interpretação constitucional das normas de competência tributária (atributivas e desonerativas)". Interesse Público. Belo Horizonte : Editora Fórum, ano 11, n 57 , set./out. 2009, p. 157-171. 
É de se ver que a norma constitucional, em sua literalidade, não vinculou expressamente os livros, jornais e periódicos ao insumo papel, apenas a ele também se referindo como mais um dos bens jurídicos objeto da exoneração em tela, sem que, outrossim, tenham sido explicitados os motivos que levaram a se estabelecer a delimitação da competência tributária dessa maneira.

As suas finalidades extrajurídicas, assim, são conhecidas como sendo o amparo, estimulo e difusão da cultura (entendida enquanto manifestação do ser humano), através dos livros, periódicos e jornais, fomentando o desenvolvimento pela aprendizagem do indivíduo ao mesmo tempo em que se viabiliza a manifestação irrestrita e livre do pensamento, inclusive no exercício crítico ou de promoção partidária, conforme se extrai mais precisamente das diretrizes de políticas públicas nacionais para o livro, tal qual dispostas no art. $1^{\circ}$, II e IX, da Lei no $10.753 / 03$.

Essa inspiração política de liberdade de pensamento, cultural e desenvolvimentista se estende igualmente ao insumo, ao meio básico, tradicional e mais comum de veiculação das publicações, qual seja, o papel de impressão $0^{5}$; saber-se se somente a ele, nesses tempos de grande avanço tecnológico, é o hodierno desafio aos exegetas tributário-constitucionais.

Nesse contexto, essa norma constitucional-tributária desonerativa, verdadeira condicionante endógena parcial, na dicção de Aires Fernandino Barreto ${ }^{6}$ - vez dirigir-se apenas aos impostos -, objetiva ou real - vez ser em função do objeto alvo

5 Observa-se, de antemão, que sob um prisma eminentemente pragmático, essa espécie de exoneração tributária propicia o barateamento do custo e das atividades que instrumentam o expediente de produção das obras literárias, vez que atinge diretamente o insumo mais comum e usual para a veiculação de qualquer mensagem que se queira propalar.

6 "Limites da competência tributária municipal". In: GASPARINI, Diogenes et alii. O Município e a constituinte: anais do XI encontro nacional de procuradores municipais. COSTA, Irany Gonçalves da (Coord.). Uberlândia : ABC-SABE, 1985, p. 87-89. 
da exação ${ }^{7}$-, deve ser interpretada dentro de uma integração evolutiva, mediante o emprego da técnica construtivista das normas constitucionais, conforme já se asseverou ${ }^{8}$.

Isso significa que através da interpretação evolutiva, otimizada pelo construtivismo constitucional, é que se descobre se a imunidade tributária em tela pode ser estendida aos demais insumos à luz de um conceito amplo de "livro", inclusive considerando-se os primados positivados nessa previsão constitu-

7 Ruy Barbosa Nogueira assim externou suas lições a respeito dessa classificação das exonerações tributárias: Subjetiva é a incidência, isenção ou imunidade prevista em razão da pessoa: ratione personae. Objetiva é a incidência, isenção ou imunidade prevista em razão do objeto tributado: ratione materiae. Subjetiva-objetiva - na amplitude da casuística das situações, às vezes deparamos com disposições que levam em conta não só aspectos objetivos mas, concomitantemente, subjetivos. Nem sempre é fácil destacar a predominância ou maior carga de um desses dois aspectos. Se na vontade objetiva na lei ordinária ou na Constituição transparecem ambos é porque estes aspectos estão consorciados.(Curso de direito tributário. São Paulo : Saraiva, 1995, p. 169-170).

8 É o construtivismo constitucional, há muito lecionado por José Horácio Meirelles Teixeira e mais contemporaneamente esclarecido por Luís Roberto Barroso. O construtivismo não inova aquilo constitucionalmente estipulado, sendo a maneira mais autorizada de se obter, em um caso concreto, não expressamente previsto na norma constitucional, o seu verdadeiro conteúdo de aplicação... Essa técnica construtivista de interpretação constitucional expressa, na aplicação do Direito ao fato concreto, a necessidade de uma adaptação evolutiva que o sistema jurídico deve ter diante das alterações naturais e constantes do sistema social para que não entre em colapso por conta do seu fechamento operacional, correspondendo, em ultima ratio, à técnica interpretativa que incorpora as alterações sociais valorativas mais fundamentais mediante a aplicação contemporânea do direito positivo. Vê-se, claramente, que a interpretação evolutiva, por meio da técnica construtivista, é a única capaz de haurir, do prisma cognitivo do sistema jurídico, a precisa dimensão semântico-pragmática indeclinável para que os conflitos possam ser adequadamente regrados (e decididos em atenção aos fins sociais e às exigências do bem comum, à luz do art. $5^{a}$, da Lei $n^{\circ} 4.657$, de 04 de setembro de 1942 - Lei de Introdução ao Código Civil) e, no estudo ora realizado, permitir uma melhor identificação das normas de competência tributária (atributivas e desonerativas) na Constituição Federal de 1988 (CALDAS, Roberto Correia da Silva Gomes. "Breves considerações em torno da interpretação constitucional das normas de competência tributária (atributivas e desonerativas)". Interesse Público. Belo Horizonte : Editora Fórum, ano 11, $n^{\circ} 57$, set./out. 2009, p. 165-166). É de se guardar na retentiva que na interpretação constitucional, um método não exclui o outro durante o processo de busca do sentido da norma, havendo apenas a prevalência de um, ou uns, em relação aos demais, conforme a circunstância enfocada. E sobre a diferenciação entre as técnicas interpretativas constitucionais, quais sejam, a evolutiva, a da mutação e a da construção, ver-se as precisas e objetivas lições de Eduardo Ribeiro Moreira ("Conselhos constitucionais". Revista de direito constitucional e internacional : Cadernos de direito constitucional e ciência política. São Paulo : Editora Revista dos Tribunais, ano 18, n 71, abr./jun. 2010, p. 59-61). 
cional, ou se a menção expressa ao papel de impressão é vinculante à idéia jurídica que dele se deve ter.

E, dentre os percalços mais comuns a serem enfrentados pelos intérpretes dessa espécie de imunidade tributária, conforme se extrai da casuística, tem-se, por exemplo, as tentativas do Fisco de tributar periódicos ou publicações de teor especializado, pretensamente desprovidos do intuito difusor cultural $^{9}$, ou, ainda, itens publicitários que se revelariam desvinculados dos propósitos imunizantes ${ }^{10}$. Outra situação de dificul-

9 O preceito da alínea $\boldsymbol{d}$ do inciso VI do artigo 150 da Carta da República alcança as chamadas apostilas, veículo de transmissão de cultura simplificado (RE 183.403, Rel. Min. Marco Aurélio, julgamento em 7-11-00, DJ de 4-5-01. Disponível em: <http://redir.stf.jus.br/paginador/paginador.jsp?docTP=AC\&doc IID=227327>. Acesso em: 05/03/2011); 'Álbum de figurinhas'. Admissibilidade. A imunidade tributária sobre livros, jornais, periódicos e o papel destinado à sua impressão tem por escopo evitar embaraços ao exercício da liberdade de expressão intelectual, artística, científica e de comunicação, bem como facilitar o acesso da população à cultura, à informação e à educação. O Constituinte, ao instituir esta benesse, não fez ressalvas quanto ao valor artístico ou didático, à relevância das informações divulgadas ou à qualidade cultural de uma publicação. Não cabe ao aplicador da norma constitucional em tela afastar este benefício fiscal instituído para proteger direito tão importante ao exercício da democracia, por força de um juízo subjetivo acerca da qualidade cultural ou do valor pedagógico de uma publicação destinada ao público infanto-juvenil (RE 221.239, Rel. Min. Ellen Gracie, julgamento em 25-5-04, DJ de 6-8-04; Disponível em: <http://redir.stf.jus.br/paginador/ paginador.jsp?docTP=AC\&docID=249506>. Acesso em: 05/03/2011). No mesmo sentido: RE 179.893, Rel. Min. Menezes Direito, julgamento em 15-4-08, $1^{\text {a }}$ Turma, DJE de 30-5-08 (Disponível em: <http://redir.stf.jus.br/paginador/paginador. jsp?docTP=AC\&doc $I D=530461>$. Acesso em: 05/03/2011). Imunidade tributária (livros, jornais e periódicos): listas telefônicas. Firmou-se a jurisprudência do STF no sentido de que a imunidade constitucional assegurada à publicação de periódicos impede a cobrança de ISS sobre a edição de listas telefônicas (RE 114.790, Rel. Min. Sepúlveda Pertence, julgamento em 12-8-97, DJde 3-10-97; Disponível em: <http://redir.stf.jus.br/paginador/paginador.jsp? docTP=AC\&doclD=205100>. Acesso em: 05/03/2011).

10 Encartes de propaganda distribuídos com jornais e periódicos. ISS. Art. 150, VI, d, da Constituição. Veículo publicitário que, em face de sua natureza propagandística, de exclusiva índole comercial, não pode ser considerado como destinado à cultura e à educação, razão pela qual não está abrangido pela imunidade de impostos prevista no dispositivo constitucional sob referência, a qual, ademais, não se estenderia, de qualquer forma, às empresas por eles responsáveis, no que concerne à renda bruta auferida pelo serviço prestado e ao lucro líquido obtido (RE 213.094, Rel. Min. IImar Galvão, julgamento em 3-8-99, DJ de 15-10-99; Disponível em: <http://redir.stf.jus.br/paginador/paginador.jsp?docTP=AC\&doc $I D=244565>$. Acesso em: 05/03/2011). O fato de as edições das listas telefônicas veicularem anúncios e publicidade não afasta o benefício constitucional da imunidade. A inserção visa a permitir a divulgação das informações necessá- 
dade que se pode mencionar, é a dúvida a respeito de a imunidade sub examine abarcar apenas os impostos ou também os demais tributos ${ }^{11}$, relacionados ou não aos demais insumos ${ }^{12}$. E,

rias ao serviço público a custo zero para os assinantes, consubstanciando acessório que segue a sorte do principal. Precedentes : Recurso Extraordinário $n$. 101.441/RS, Pleno, Relator Ministro Sydney Sanches, RTJ n 126, página 216 à 257, Recurso Extraordinário n. 118.228/SP, Primeira Turma, Relator Ministro Moreira Alves, RTJ n. 131, página 1.328 à 1.335, e Recurso Extraordinário $n$. 134.071-1/SP, Primeira Turma, Relator Ministro IImar Galvão, Diário da Justiça de 30 de outubro de 1992 (RE 199.183, Rel. Min. Marco Aurélio, julgamento em 174-98,DJ de 12-6-98; Disponível em: <http://redir.stf.jus.br/paginador/paginador. jsp?docTP=AC\&doclD=236553>. Acesso em: 05/03/2011).

11 A imunidade prevista no art. 150, VI da Constituição Federal não alcança a contribuição para o PIS, mas somente os impostos incidentes sobre a venda de livros, jornais e periódicos (RE 211.388-ED, Rel. Min. Maurício Corrêa, julgamento em 10-2-98, DJ de 8-5-98; Disponível em: <http://redir.stf.jus.br/ paginador/ paginador.jsp?docTP=AC\&docID=50360>. Acesso em: 16/02/2011). Sendo as contribuições para o FINSOCIAL modalidade de tributo que não se enquadra na de imposto, segundo o entendimento desta Corte em face do sistema tributário da atual Constituição, não estão elas abrangidas pela imunidade tributária prevista no artigo 150, VI, d, dessa Carta Magna, porquanto tal imunidade só diz respeito a impostos (RE 141.715, Rel. Min. Moreira Alves, julgamento em 184-95, DJ de 25-8-95; Disponível em: <http://redir.stf.jus.br/paginador/paginador. jsp?docTP=AC\&doclD=208951>. Acesso em: 05/03/2011). A imunidade tributária prevista na alínea "d" do inciso VI do artigo 150 da Constituição do Brasil não alcança as contribuições para a seguridade social, não obstante sua natureza tributária, vez que imunidade diz respeito apenas a impostos. Precedentes (RE 342336 AgR / RS, Rel. Min. Eros Grau, julgamento em 20-03-07, DJe de 17-507; Disponível em: <http://www.stf.jus.br/portal/inteiroTeor/obterlnteiroTeor.asp? $\mathrm{id}=452060$. . Acesso em: 05/03/2011).

12 Imunidade conferida pelo art. 150, VI, d da Constituição. Impossibilidade de ser estendida a outros insumos não compreendidos no significado da expressão 'papel destinado à sua impressão'. Precedentes do Tribunal (RE 324.600-AgR, Rel. Min. Ellen Gracie, julgamento em 3-9-02, DJ de 25-10-02; Disponível em: <http:// redir.stf.jus.br/paginador/paginador.jsp?docTP=AC\&docID=351956>. Acesso em: 05/03/2011). No mesmo sentido: RE 244.698-AgR, Rel. Min. Ellen Gracie, julgamento em 7-8-01, DJ de 31-8-01 (Disponível em: <http://redir.stf.jus.br/paginador/paginador.jsp?docTP=AC\&docID=333415>. Acesso em: 05/03/2011). Não há de ser estendida a imunidade de impostos prevista no dispositivo constitucional sob referência, concedida ao papel destinado exclusivamente à impressão de livros, jornais e periódicos, aos serviços de composição gráfica necessários à confecção do produto final (RE 230.782, Rel. Min. Ilmar Galvão, julgamento em 13-6-00, DJ de 10-11-00; Disponível em: <http://redir.stf.jus.br/paginador/ paginador.jsp?docTP=AC\&docID=253467>. Acesso em: 05/03/2011). ICMS. Imunidade tributária que alcança os materiais relacionados com o papel. Art. 150, VI, d, da Constituição Federal. Precedentes. Agravo regimental em que se pretende o reexame da matéria, com base na alínea $c$ do inciso VI do art. 150 da Constituição Federal, por se tratar de entidade sindical de trabalhadores. Acórdão do Tribunal de origem que, com base em elementos probatórios dos autos, assentou que as impressões gráficas realizadas pelo Impetrante estão dissociadas de 
dentre os insumos, algumas situações já se mostram pacificadas, como é exemplo a do papel fotográfico e filme, à luz da Súmula no 657 do Supremo Tribunal Federal, de 200313.

sua atividade essencial (RE 281.901-AgR, Rel. Min. Néri da Silveira, julgamento em 12-6-01, DJ de 31-8-01; Disponível em: <http://redir.stf.jus.br/paginador/paginador.jsp? docTP=AC\&docID=336500>. Acesso em: 05/03/2011). Jornal. Imunidade tributária. CF, art. 150, VI, d. O Supremo Tribunal Federal decidiu que apenas os materiais relacionados com papel (papel fotográfico, papel telefoto, filmes fotográficos, sensibilizados, não impressionados, para imagens monocromáticas, papel fotográfico $p /$ fotocomposição por laser) é que estão abrangidos pela imunidade tributária do art. 150, VI, d, da CF (RE 178.863, Rel. Min. Carlos Velloso, julgamento em 25-3-97, $2^{\mathrm{a}}$ Turma, DJ de 30-5-97; Disponível em: <http:// redir.stf.jus.br/paginador/paginador.jsp?docTP=AC\&doc ID=224076>. Acesso em: 05/03/2011). No mesmo sentido: RE 495.385-AgR, Rel. Min. Eros Grau, julgamento em 29-9-09, $2^{\text {a }}$ Turma, DJE de 23-10-09 (Disponível em: <http://redir.stf.jus.br/paginador/paginador.jsp?docTP $=A C \& d o c I D=604661>$. Acesso em: 05/03/2011).

13 A imunidade prevista no art. 150, VI, d, da CF abrange os filmes e papéis fotográficos necessários à publicação de jornais e periódicos (Súmula $n^{\circ} 657$, do Supremo Tribunal Federal). Extensão da imunidade tributária aos insumos utilizados na confecção de jornais. Além do próprio papel de impressão, a imunidade tributária conferida aos livros, jornais e periódicos somente alcança o chamado papel fotográfico - filmes não impressionados (RE 203.859, Rel. Min. Carlos Velloso, julgamento em 11-12-06, Plenário, DJ de 24-8-01; Disponível em: <http:// redir.stf.jus.br/paginador/paginador.jsp?docTP=AC\&doclD=238998>. Acesso em: 05/03/2011). No mesmo sentido: RE 495.385-AgR, Rel. Min. Eros Grau, julgamento em 29-9-09, $2^{\text {a }}$ Turma, DJE de 23-10-09 (Disponível em: <http://redir.stf.jus.br/paginador/paginador.jsp?docTP $=A C \& d o c I D=604661>$. Acesso em: 05/03/2011); RE 273.308, Rel. Min. Moreira Alves, julgamento em 22-8-00, $1^{\text {a }}$ Turma, $D J$ de 15-9-00 (Disponível em: <http://redir.stf.jus.br/paginador/paginador. jsp?docTP $=$ AC\&docID=259514 $>$. Acesso em: 05/03/2011). Imunidade tributária (CF, art. 150, VI, d): filmes destinados à produção de capas de livros. É da jurisprudência do Supremo Tribunal que a imunidade prevista no art. 150, VI, d, da Constituição, alcança o produto de que se cuida na espécie (Filme Bopp) (Al 597.746-AgR, Rel. Min. Sepúlveda Pertence, DJ 07/12/06; Disponível em: <http://redir.stf.jus.br/paginador/ paginador.jsp?docTP=AC\&doclD=394244>. Acesso em: 05/03/2011). Papel: filmes destinados à produção de capas de livros. CF, art. 150, VI, d. Material assimilável a papel, utilizado no processo de impressão de livros e que se integra no produto final - capas de livros sem capa-dura - está abrangido pela imunidade do art. 150, VI, d. Interpretação dos precedentes do Supremo Tribunal Federal, pelo seu Plenário, nos RREE 174.476/ SP, 190.761/SP, Ministro Francisco Rezek, e 203.859/SP e 204.234/RS, Ministro Maurício Corrêa (RE 392.221, Rel. Min. Carlos Velloso, julgamento em 185-04, DJ de 11-6-04; Disponível em: <http://redir.stf.jus.br/paginador/paginador. jsp?docTP=AC\&docID=261704>. Acesso em: 05/03/2011). $A$ imunidade prevista no art. 150, VI, d, da Carta Magna, alcança tão somente os filmes e papéis tidos por necessários à publicação de livros, jornais e periódicos, tais como o papel fotográfico, inclusive o destinado a fotocomposição por laser, os filmes fotográficos, sensibilizados, não impressionados, para imagens monocromáticas, e o papel para telefoto (súmula 657) (Al n 530.958/GO; Rel. Min. Cezar Peluso; julgamento 
A questão, todavia, se torna ainda mais complexa e delicada quando apercebe-se que o atual estádio tecnológico da humanidade põe à disposição uma gama de recursos audiovisuais, de caráter cultural ou científico, que esbarra não apenas nessa tão variada discricionariedade judicial acima comentada, como também em certo subjetivismo doutrinário, com significativa diversidade de opiniões, situação esta tão temida e indesejada pela sociedade como um todo (e não apenas pelo constituinte). Daí Sacha Calmon Navarro Coêlho antever que (...) a imunidade sob crivo terá o seu perfil desenhado pelas convicções morais, políticas e religiosas dos juizes ${ }^{14}$.

E, como exemplificação desse subjetivismo e diversidade de abordagens doutrinárias sobre o tema, trazem-se à colação algumas lições, como as de Edvaldo Brito, Sacha Calmon Navarro Coêlho e Heleno Taveira Tôrres com Vanessa Nobell Garcia, em torno das variantes tecnológicas. $\mathrm{O}$ primeiro autor, de seu lado, pondera que o software pode ora ser entendido enquanto serviço e ora ser havido como mercadoria, alternando-se, assim, a competência tributária entre os entes de direito público interno, concluindo pela incidência da exoneração tributária como justificativa para afastar eventual conflito de competência ${ }^{15}$. O segundo, malgrado faça a mesma alusão

em 31/3/05; Disponível em: <http://www.stf.jus.br/portal/diarioJustica/ verDiarioProcesso.asp? numDj=61\&dataPublicacaoDj $=31 / 03 / 2005 \&$ incidente $=2270318 \& \mathrm{c}$ odCapitulo=6\&numMateria=38\&codMateria=3>. Acesso em: 05/03/2011). I. Papel, papel fotográfico e papel para artes gráficas consumidos no processo produtivo do jornal estão cobertos pela imunidade tributária do art. 150, VI, d, da Constituição Federal. II. Precedentes do Supremo Tribunal Federal: RREE 190.761-SP e 174.476-SP (RE 276.842-ED, Rel. Min. Carlos Velloso, DJ 15-3-02; Disponível em: <http://redir.stf.jus.br/ paginador/ paginador.jsp?docTP= AC\&docID=51548>. Acesso em: 05/03/2011).

14 Comentários à Constituição de 1998 - sistema tributário. Rio de Janeiro : Forense, $8^{a}$ ed., 1999, p. 305.

15 Afirma que Nestes termos, as relações entre o Direito Tributário e o Direito Informático conduzem a que se respeitem os conceitos formulados por este último, quando o contrário der como conseqüência o conflito de competência. Então, praticamente, tem-se que software, enquanto pensamento ou enquanto seja aquilo que se tem chamado de lógica, é atividade intelectual, logo, enquadra-se como serviço na linguagem tributária, isto é, prestação de uma obrigação de fazer e, se fosse tributada a respectiva operação, sê-lo-ia pelo imposto, de competência do Município, incidente sobre serviços de qualquer natureza; tem-se 
ao cunho ora de mercadoria e ora de serviço do software, acaba por concluir que a norma constitucional não se aplica ao livro eletrônico para livrá-lo da tributação ${ }^{16}$. Já os outros autores retro-referidos, a seu turno, entendem que a vultosa expressão econômica dos softwares, em comparação aos livros impressos em papel, revela uma capacidade tributária dos seus adquirentes que não justifica a imunidade em comento restando a si estendida, exceção sendo feita, tão-só, quando havidos enquanto meros acompanhantes ou complementos do livro em sua versão tradicional ${ }^{17}$.

Alguns outros doutrinadores, como Aires Fernandino Barreto e Paulo Aires Barreto, defendem que tal imunidade

que software enquanto disquete, cassete etc., veiculando programas padronizados (package), enquadra-se como mercadoria na linguagem tributária, isto é, prestação de uma obrigação de dar coisa, e se fosse tributada a respectiva operação sê-lo-ia pelo imposto, de competência do Estado, incidente sobre operações relativas à circulação dessas mercadorias ["O livro eletrônico é imune". In: BARRETO, Aires Fernandino et alii. Imunidade tributária do livro eletrônico. MACHADO, Hugo de Brito (Coord.). São Paulo : Gráfica Editora Itda. (IOB Informações Objetivas), 1998, p. 49].

16 ...CD de prateleira sujeita-se ao ICMS. Programas feitos sob encomenda sujeitam-se ao ISS. Livros e jornais transmitidos pelas TVs a cabo e estradas de informação não são "coisa" nem "serviços"... (...) Respeitemos o tempo e o ambiente social, cultural e legislativo em que foi gestada a imunidade prevista no art. 150, inciso VI, alínea d, da Constituição Federal. Ela, a toda evidência, não se aplica ao "livro eletrônico". A imunidade teve a sua razão de ser, no funil do tempo evanescente. Perecerá - como tudo que é vivo perece - na mesma medida que a humanidade caminhar para cima e para o alto ("A imunidade dos livros, jornais, periódicos e do papel destinado a sua impressão". In: BARRETO, Aires Fernandino et alii. Imunidade tributária do livro eletrônico. MACHADO, Hugo de Brito (Coord.). São Paulo : Atlas, $2^{\mathrm{a}}$ ed., 2003, p. 280 e 281).

17 Cogitam que a omissão do constituinte, afeito aos recursos modernos, é proposital, afinal,... Revela-se muito bem evidenciado que a capacidade econômica dos adquirentes de softwares e CD-ROMs lhes permite consumir tais produtos sem que a tributação incidente se mostre como uma limitação decisiva ao valor liberdade por ela garantido. Não há razão de legítima justiça que autorize a esses usuários servir-se de tal benefício, de um privilégio a mais sem a menor justificativa em termos de capacidade contributiva e de justiça fiscal, principalmente (sic). Admitem a invocação imunizatória se (...) o CD-ROM, fita de vídeo ou disquete acompanhe livro, jornal ou periódico e desde que possua conteúdo idêntico e complementar àqueles, com a preponderância econômica do livro, do jornal e do periódico, então, e só neste caso, aplica-se a regra imunitória a todo o conjunto [“Tributação e imunidade dos chamados 'livros eletrônicos'”. In: BARRETO, Aires Fernandino et alii. Imunidade tributária do livro eletrônico. MACHADO, Hugo de Brito (Coord.). São Paulo : Gráfica Editora Itda. (IOB Informações Objetivas), 1998, p. 85-86; Ibidem, São Paulo : Atlas, $2^{\text {a }}$ ed., 2003, p. 94-95 e 96]. 
deve abarcar, igualmente, os serviços voltados à confecção dos livros, jornais e periódicos, como também o rádio e a televisão, veículos de comunicação importantes para a difusão e fomento da informação, inclusive aos analfabetos ${ }^{18}$. Em sentido oposto, há quem propugne a interpretação de tal imunidade tributária por um viés mais restritivo, isto é, de mais objetividade, rechaçando sua alegação pelas empresas jornalísticas, editoriais, ou mesmo pelos livreiros e autores, caso a atividade desempenhada não se mostre relacionada com o insumo "papel”, maxime à luz do art. 9o, IV, “d”, do Código Tributário Nacional (o que signi-

18 Em sua doutrina, expõem que (...) tributar os serviços próprios, indispensáveis, ínsitos ao livro, ao jornal e aos demais periódicos, importa onerar esses bens, incorrendo na proibição constitucional. É igualmente manifesto que tributar atividade sem a qual o livro, o jornal ou outros periódicos não podem chegar às mãos dos leitores, incide também na vedação constitucional (Imunidades tributárias: limitações constitucionais ao poder de tributar. São Paulo : Dialética, $1^{\text {a }}$ ed., 1999, p. 88). Esses autores concentram seus esforços interpretativos no aspecto social que verificam como indissociável dessa imunidade e em consonância com os demais dispositivos constitucionais pertinentes: Enquanto a erradicação do analfabetismo (art. 214) é mera promessa (já lá se vão os dez anos a que se refere o art. 60 do ADCT), como subtrair a tantos desfavorecidos o direito de receberem informação e educação, senão por meio de jornais e de outros programas educativos, em rádios e televisões? A realização do princípio da igualdade (art. $5^{\circ}$, caput, e seu inciso I) exige que essas pessoas recebam tratamento compatível com suas dificuldades e deficiências. Imunizar o jornal escrito e não o falado ou televisionado é inverter o princípio da isonomia, é pô-lo às avessas, privilegiando quem sabe ler e marginalizando quem não o sabe (Ibidem, p. 89). Em sentido contrário a esta acertada postura doutrinária, por maioria de votos, o Supremo Tribunal Federal deferiu a medida cautelar para suspender, no texto da alínea "d" do inciso VI do art. 193 da Constituição do Estado do Rio de Janeiro, as expressões "e veículos de radiodifusões", bem como, no texto do inciso XIV do art. 40 da Lei estadual $n^{\circ} 1.0423$, de 27.07 .89 , as expressões "e veículo de radiodifusão", vencidos, em parte, os Mins. Relator e Francisco Rezek, que indeferiam a medida cautelar, tendo votado o então Presidente. Tal medida cautelar, cuja ementa a seguir se transcreve, é a que prevalece no caso, pois aguarda-se julgamento definitivo da questão de inconstitucionalidade desde 2003: Constituição do Estado do Rio de Janeiro, art. 193, inciso VI, d; Lei n. 1.423, de 27-1-89, do mesmo Estado, art. 40, inciso XIV. Extensão aos veículos de radiodifusão da imunidade tributária prevista na Constituição Federal para livros, jornais, periódicos e o papel destinado a sua impressão. Relevância jurídica do pedido e periculum in mora caracterizados. Medida cautelar deferida, para suspender, ex nunc e até o julgamento final da ação, na alínea d, do inciso VI, do art. 193, da Constituição do Estado do Rio de Janeiro, as expressões 'e veículos de radiodifusão', bem como no inciso XIV, do art. 40, da Lei fluminense n. 1.423, de 27-1-1989, as expressões 'e veículos de radiodifusão' (ADI 773-MC, Rel. Min. Néri da Silveira, julgamento em 9-9-92, DJ de 30-4-93; Disponível em: <http://redir.stf.jus.br/paginador/paginador.jsp?docTP=AC\&docID=346596>. Acesso em: 05/03/2011). 
fica entender-se a exoneração em foco como em função do papel destinado exclusivamente à impressão de jornais, periódicos e livros) $)^{19}$.

Vê-se, assim, que somente uma análise criteriosa a respeito do que se deve entender por "livro" - e seu respectivo insumo - é que autorizará o intérprete chegar a uma conclusão precisa sobre o dito "livro eletrônico", sendo isso, portanto, o que se passa a fazer.

19 Dentre tais doutrinadores tem-se: COÊLHO, Sacha Calmon Navarro. "A imunidade dos livros, jornais, periódicos e do papel destinado a sua impressão". In: BARRETO, Aires Fernandino et alii. Imunidade tributária do livro eletrônico. MACHADO, Hugo de Brito (Coord.). São Paulo : Atlas, $2^{a}$ ed., 2003, p. 273-281; HARADA, Kiyoshi. "Imunidade tributária". In: MARTINS, Ives Gandra da Silva et alii. Imunidades tributárias. MARTINS, Ives Gandra da Silva (Coord.). São Paulo : co-edição Centro de Extensão Universitária e Revista dos Tribunais, 1998, p. 454; MORAES, Bernardo Ribeiro de. "A imunidade tributária e seus novos aspectos". In: MARTINS, Ives Gandra da Silva et alii. Imunidades tributárias. MARTINS, Ives Gandra da Silva (Coord.). São Paulo : co-edição Centro de Extensão Universitária e Revista dos Tribunais, 1998, p. 133-139. ROCHA, Valdir de Oliveira. "Imunidade tributária". In: MARTINS, Ives Gandra da Silva et alii. Imunidades tributárias. MARTINS, Ives Gandra da Silva (Coord.). São Paulo : co-edição Centro de Extensão Universitária e Revista dos Tribunais, 1998, p. 317318; SANTI, Eurico Marcos Diniz de. "Imunidade tributária como limite objetivo e as diferenças entre 'livro' e 'livro eletrônico'”. In: BARRETO, Aires Fernandino et alii. Imunidade tributária do livro eletrônico. MACHADO, Hugo de Brito (Coord.). São Paulo : Atlas, $2^{\text {a }}$ ed., 2003, p. 55-67; SARAIVA FILHO, Oswaldo Othon de Pontes. "Os CD-ROMs e disquetes com programas gravados são imunes?". Revista dialética de direito tributário. São Paulo : Dialética, $\mathrm{n}^{\circ} 7$, abr. 1996, p. 36-37; Idem. "A não-extensão da imunidade aos chamados livros, jornais e periódicos eletrônicos". Revista dialética de direito tributário. São Paulo : Dialética, $n^{\circ} 33$, jun. 1998, p. 138. TORRES, Ricardo Lobo. "Imunidade tributária nos produtos de informática". In: BARRETO, Aires Fernandino et alii. Imunidade tributária do livro eletrônico. MACHADO, Hugo de Brito (Coord.). São Paulo : Atlas, $2^{a}$ ed., 2003, p. 234-236 e 238. Nesse diapasão é a jurisprudência do Supremo Tribunal Federal, consoante se extrai do seguinte paradigma: Anistia do art. 150, VI, d, da Constituição Federal. IPMF. Empresa dedicada à edição, distribuição e comercialização de livros, jornais, revistas e periódicos. Imunidade que contempla, exclusivamente, veículos de comunicação e informação escrita, e o papel destinado a sua impressão, sendo, portanto, de natureza objetiva, razão pela qual não se estende às editoras, autores, empresas jornalísticas ou de publicidade-que permanecem sujeitas à tributação pelas receitas e pelos lucros auferidos. Conseqüentemente, não há falar em imunidade ao tributo sob enfoque, que incide sobre atos subjetivados (movimentação ou transmissão de valores e de créditos e direitos de natureza financeira) (RE 206.774, Rel. Min. IImar Galvão, julgamento em 3-899, DJ de 29-10-99; Disponível em: <http://redir.stf.jus.br/ paginador/paginador. jsp?docTP=AC\&doclD=240706>. Acesso em: 05/03/2011). 


\section{CONSIDERAÇÕES EM TORNO DA INTERPRETAÇÃO DA IMUNIDADE TRIBUTÁRIA SOBRE O LIVRO ELETRÔNICO}

O primeiro objeto de perquirição e altercação sobre esse assunto é relacionado à própria existência do conceito jurídico de "livro", principalmente quando seu conteúdo é veiculado por outro meio que não seja o papel ${ }^{20}$.

A indagação é extremamente oportuna tendo em vista o manuseio da tecnologia contemporânea que não se limita mais às formas tradicionais de armazenamento, acondicionamento e reprodução de informações, em contraponto a uma hodierna conceituação de "livro" para efeitos da sua política pública nacional, positivada de forma estreita e amesquinhadora de sua possível extensão, vez relacioná-lo, atrelá-lo, com boa parte dos seus congêneres equiparáveis, ao tradicional insumo havido a partir da celulose (art. 2 ${ }^{\circ}$ caput e parágrafo único, I, II, IV, VI e VIII, da Lei no $10.753 / 03)^{21}$.

Os novos veículos de difusão de idéias se diversificam diariamente: CD's, CD-ROM's, CDR's, CDR-W's, DVD's, fitas

20 A respeito da importância da indagação em torno da definição do vocábulo "livro", Felippe Daudt de Oliveira salienta que... se conseguirmos resgatar a verdadeira essência daquilo que chamamos de livro, poderemos determinar o maior ou menor alcance da imunidade prevista no art. 150; e é isso o que pretendemos fazer neste trabalho, visando a que o espírito do relevante dispositivo constitucional seja integralmente apreendido e honrado ("O sentido da palavra livro no art. 150 da Constituição Federal - proteção da uma essência e não de um nome". In: BARRETO, Aires Fernandino et alii. Imunidade tributária do livro eletrônico. MACHADO, Hugo de Brito (Coord.). São Paulo : Atlas, $2^{a}$ ed., 2003, p. 69).

21 O Tribunal de Justiça de São Paulo já decidiu que Livro é o instrumento apto para receber e difundir a expressão gráfica do pensamento. O adjetivo "didático" qualifica o que é relativo ao ensino ou à instrução, próprio ou destinado a instruir. Didática, por sua vez, é a arte de ensinar, de acordo com métodos definidos, adaptando as lições à idade do discípulo, à sua inteligência, ao grau de seus conhecimentos e à maior ou menor dificuldade da coisa cujo ensino se ministra. Didáticos, pois, não são necessariamente apenas os livros adotados nas escolas, mas todos aqueles que tenham a aptidão para desenvolver as potencialidades da pessoa humana. De acordo com a Resolução n. 113, de 31.3.76, da Secretaria da Educação, é recomendável que o título dos livros dirigidos às crianças seja "sugestivo, cativante e com ilustrações criteriosamente coloridas". Propõe, ainda, que solicitem e agucem a criatividade através de textos e desenhos (RJTJESP - Revista de Jurisprudência do Tribunal de Justiça do Estado de São Paulo. São Paulo : LEX, ano 18, vol. 87, $2^{\circ}$ bim., marlabr 1984, p. 113-114). 
magnéticas de áudio e vídeo, dentre outras modalidades como os mais recentes "Tablets", os quais comportam uma verdadeira biblioteca em suas memórias.

E sobre tal circunstância de se conceituar "livro", Eurico Marcos Diniz de Santi, na doutrina pátria, detém-se na hermenêutica do dispositivo constitucional para concluir que o valor informado na regra, nela se esgota, bem como nas propriedades dos objetos contrapostos, de modo que, em interpretação pro domo sua, o livro, enquanto tal, assim o será somente se veiculado de forma a permitir acesso imediato ao seu conteúdo pelo leitor, ou seja, em papel22.

No estudo que ora se empreende, todavia, diverge-se dessa doutrina que nega a existência jurídica do livro por outros meios de disseminação que não seja o papel, para efeitos da imunidade tributária ${ }^{23}$. Ora, se o objetivo da imunidade tribu-

22 O livro exige do leitor participação imediata, atenta e reflexiva. Assim, seja em papiro, em casca de árvore, em papel, plástico ou madeira, o livro exige essa destinação, imediata e pronta, para o consumo do intérprete humano. Por isso, em decorrência da característica intrínseca ao livro, não podemos admitir qualquer tentativa de equiparação dele ao CD-ROM, nem à fita magnética, nem ao disco de acetato, nem aos slides ou outras formas de comunicação que exijam a interposição de máquina decodificadora para viabilizar o acesso humano ["Imunidade tributária como limite objetivo e as diferenças entre 'livro' e 'livro eletrônico'". BARRETO, Aires Fernandino et alii. Imunidade tributária do livro eletrônico. MACHADO, Hugo de Brito (Coord.). São Paulo: Gráfica Editora Itda. (IOB Informações Objetivas), 1998, p. 55; Ibidem, São Paulo : Atlas, $2^{a}$ ed., 2003, p. 60].

23 A favor da existência da imunidade tributária sobre o livro eletrônico, tem-se, dentre muitos outros: PACHECO, Angela Maria da Motta. "Imunidade tributária do livro". In: BARRETO, Aires Fernandino et alii. Imunidade tributária do livro eletrônico. MACHADO, Hugo de Brito (Coord.). São Paulo : Atlas, $2^{\mathrm{a}}$ ed., 2003, p. 14-29; CAMPOS, Dejalma de; CAMPOS, Marcelo. "A imunidade e as garantias constitucionais - alcance do artigo 150, VI, $d$, da CF". In: BARRETO, Aires Fernandino et alii. Imunidade tributária do livro eletrônico. MACHADO, Hugo de Brito (Coord.). São Paulo : Atlas, $2^{a}$ ed., 2003, p. 30-34; BRITO, Edvaldo. "O livro eletrônico é imune". In: BARRETO, Aires Fernandino et alii. Imunidade tributária do livro eletrônico. MACHADO, Hugo de Brito (Coord.). São Paulo : Atlas, $2^{\text {a }}$ ed., 2003, p. 35-54; MARTINS, Ives Gandra da Silva. "Imunidades tributárias". In: BARRETO, Aires Fernandino et alii. Imunidade tributária do livro eletrônico. MACHADO, Hugo de Brito (Coord.). São Paulo : Atlas, $2^{a}$ ed., 2003, p. 121-129; NOGUEIRA, Johnson Barbosa. "A imunidade tributária do livro eletrônico". In: BARRETO, Aires Fernandino et alii. Imunidade tributária do livro eletrônico. MACHADO, Hugo de Brito (Coord.). São Paulo : Atlas, $2^{a}$ ed., 2003, p. 130-138; GONÇALVES, José Artur Lima. "A imunidade tributária do livro". In: BARRETO, Aires Fernandino et alii. Imunidade tributária do livro eletrônico. MACHADO, Hugo 
tária prevista no art. 150, VI, “d”, da Constituição Federal de 1988, é a facilitação do ensino e a divulgação da cultura ${ }^{24}$, e se o galopante avanço tecnológico dos tempos atuais permite a descoberta constante de novos meios para a difusão mais facilitada das idéias insertas nos livros, nada impede que, em um esforço exegético-integrativo, de cunho eminentemente histó-

de Brito (Coord.). São Paulo : Atlas, $2^{a}$ ed., 2003, p. 139-163; GRECO, Marco Aurelio. "Imunidade tributária do livro eletrônico". In: BARRETO, Aires Fernandino et alii. Imunidade tributária do livro eletrônico. MACHADO, Hugo de Brito (Coord.). São Paulo : Atlas, $2^{\mathrm{a}}$ ed., 2003, p. 164-176; MAIA FILHO, Napoleão Nunes. "A imunidade tributária dos livros e do papel destinado à sua impressão: (estudo tópico de exegese constitucional finalística)". In: BARRETO, Aires Fernandino et alii. Imunidade tributária do livro eletrônico. MACHADO, Hugo de Brito (Coord.). São Paulo : Atlas, $2^{\text {a }}$ ed., 2003, p. 177-187; LUNARDELLI, Pedro Guilherme Accorsi. "Imunidade sobre o livro eletrônico". In: BARRETO, Aires Fernandino et alii. Imunidade tributária do livro eletrônico. MACHADO, Hugo de Brito (Coord.). São Paulo : Atlas, $2^{\text {a }}$ ed., 2003, p. 203-222; OLIVEIRA, Ricardo Mariz de. "O sentido e o alcance da imunidade constitucional para o livro". In: BARRETO, Aires Fernandino et alii. Imunidade tributária do livro eletrônico. MACHADO, Hugo de Brito (Coord.). São Paulo : Atlas, $2^{\text {a }}$ ed., 2003, p. 239-253; CARRAZZA, Roque Antonio. "Livro eletrônico - imunidade tributária - exegese do art. 150, VI, d, da Constituição Federal". In: BARRETO, Aires Fernandino et alii. Imunidade tributária do livro eletrônico. MACHADO, Hugo de Brito (Coord.). São Paulo : Atlas, $2^{a}$ ed., 2003, p. 254-272; MACHADO, Schubert de Farias. "Imunidade do livro". In: BARRETO, Aires Fernandino et alii. Imunidade tributária do livro eletrônico. MACHADO, Hugo de Brito (Coord.). São Paulo : Atlas, $2^{a}$ ed., 2003, p. 282-291; CASSONE, Vittorio. "Imunidade tributária do livro apresentado em CD-ROM ou disquete". In: BARRETO, Aires Fernandino et alii. Imunidade tributária do livro eletrônico. MACHADO, Hugo de Brito (Coord.). São Paulo : Atlas, $2^{\mathrm{a}}$ ed., 2003, p. 292-298; OLIVEIRA, Yonne Dolacio de. "A imunidade do art. 150, inciso VI, alínea $d$ da Constituição Federal, abrange ou não o denominado livro eletrônico?". In: BARRETO, Aires Fernandino et alii. Imunidade tributária do livro eletrônico. MACHADO, Hugo de Brito (Coord.). São Paulo : Atlas, $2^{a}$ ed., 2003, p. 299-313.

24 A razão de ser da imunidade prevista no texto constitucional, e nada surge sem uma causa, uma razão suficiente, uma necessidade, está no interesse da sociedade em ver afastados procedimentos, ainda que normatizados, capazes de inibir a produção material e intelectual de livros, jornais e periódicos (RE 174.476, Rel. Min. Marco Aurélio, julgamento em 26-9--96, DJ de 12-12-97; Disponível em: <http://redir.stf.jus.br/paginador/paginador.jsp?docTP=AC\&doclD=221018>. Acesso em: 05/03/2011). E também nesse sentido: É muito fácil notarmos que, declarando o papel de imprensa imune à tributação por via de impostos, a Lei Maior teve em mira facilitar a difusão da cultura, barateando os livros, jornais e periódicos. Ora, pela mesma razão, entendemos perfeitamente sustentável que o benefício se estenda a outros insumos, que também viabilizam o atingimento deste louvável objetivo (Revista dos Tribunais: cadernos de direito constitucional e ciência política. São Paulo : Editora Revista dos Tribunais, ano 7, vol. 27, abr/ jun 1999, p. 284; MAS no 97.03.036164-1-SP - $4^{\text {a }}$ T - TRF $3^{\text {a }}$ Região - Desembargador Federal Relator Newton de Lucca - j. 26.11.97). 
rico-evolutivo e construtivo, se estenda a referida norma exoneratória também a estes vanguardistas formatos de leitura ${ }^{25}$.

Como se afirmou mais acima, a ortografia da disposição que se critica na Carta Política pátria, em si, não permite se extrair expressa vinculação do insumo papel voltado para impressão, aos livros, jornais e periódicos, de sorte que, à luz dessa realidade, ora opta-se por uma interpretação desses bens jurídicos como independentes, autônomos na redação a que submetidos ${ }^{26}$, vez ser essa, inclusive, a fórmula mais adequada para melhor se atender aos princípios e valores constitucionais a si implicados.

Trata-se, pois, de identificar-se a mens legis, ou melhor, a intentio constitutionis inspiradora da norma (contexto), e não meramente o que se verteu nela em texto, até porque, reitere-se, não obstante ser cediço que deve ser integrada a um complexo de condutas prescritivas, ações e reações dentro de um sistema jurídico, mesmo que se queira dar preponderância e apego à interpretação gramatical, no caso em estudo, esta não levaria a

25 Hugo de Brito Machado e Hugo de Brito Machado Segundo são precisos aos asseverarem que Empregado o elemento histórico, vê-se que o livro eletrônico - a mais moderna forma de livro - não existia, ou pelo menos não era significativamente difundido, ao tempo da promulgação da Constituição. Vê-se, igualmente, que os livros eletrônicos estão substituindo, gradualmente, a sua versão de papel. A cada ano a evolução e a popularidade dos meios eletrônicos aumentam bastante. É inegável, porém, que toda essa mudança na realidade não alterou o substrato daquilo que a regra editada em 1988 visa a proteger, nem tampouco os valores que motivaram a elaboração dessa regra. Uma interpretação histórico-evolutiva, portanto, conduz com segurança à conclusão de que os livros eletrônicos são imunes. Deve ser destacado, a propósito, que o emprego da interpretação histórica não significa a busca pela "vontade do legislador histórico", a fim de compreender-se o que o constituinte subjetivamente "quis" ou "deixou de querer", mas sim buscar conhecer a realidade então disciplinada para que a norma atualmente interpretada seja compreendida em consideração à evolução que se operou nessa realidade ("Imunidade tributária do livro eletrônico". In: BARRETO, Aires Fernandino et alii. Imunidade tributária do livro eletrônico. MACHADO, Hugo de Brito (Coord.). São Paulo : Atlas, $2^{a}$ ed., 2003, p. 105).

26 Dessa mesma opinião é Roque Antonio Carrazza ao asseverar que Não nos parece sustentável que a Constituição, com os dizeres "e o papel destinado a sua impressão" (alínea d, in fine), vinculou o livro ao papel, afastando, assim, da imunidade, os outros processos tecnológicos de transmissão de idéias ("Livro eletrônico - imunidade tributária - exegese do art. 150, VI, $d$, da Constituição Federal". In: BARRETO, Aires Fernandino et alii. Imunidade tributária do livro eletrônico. MACHADO, Hugo de Brito (Coord.). São Paulo : Atlas, $2^{a}$ ed., 2003, p. 265). 
caminho que implicasse afastamento de sua dimensão aqui colimada ou, ainda, desvio ou desatendimento aos fins expressos ou subjacentes a si.

De fato, a Constituição vigente estabelece em diversos dispositivos (arts. $5^{\circ}$, IV, IX, 206, II, 215, 218 e 220) a promoção da cultura, passando desde a liberdade de expressão até a garantia do ensino, sendo tais valores verdadeiros vetores diretamente implicados à imunidade tributária cuja extensão se busca desvendar. Atender a tais prescrições constitucionais de forma sistematizada consiste em um desafio lançado ao hermeneuta que se revele atento aos anseios da sociedade contemporânea e ao futuro tecnológico ${ }^{27}$, inclusive do pensar dogmático ${ }^{28}$.

27 Guiados pelo elemento sistêmico, verificamos que a regra imunizante deve estar em sintonia com as demais normas da Constituição, especialmente com aquelas que consagram os direitos e garantias fundamentais, vetores da interpretação de qualquer norma de nosso ordenamento. E assim, inevitável será a conclusão de que a interpretação abrangente da norma imunizante é a única forma de preservar tais garantias fundamentais, entre as quais estão os princípios que asseguram as liberdades de pensamento e de expressão, e que proíbem, por conseguinte, a censura, ainda quando exercida por meio de tributos (MACHADO, Hugo de Brito; MACHADO SEGUNDO, Hugo de Brito. "Imunidade tributária do livro eletrônico". In: BARRETO, Aires Fernandino et alii. Imunidade tributária do livro eletrônico. MACHADO, Hugo de Brito (Coord.). São Paulo : Atlas, $2^{a}$ ed., 2003, p. 105-106).

28 Como muito bem salienta Tércio Sampaio Ferraz Jr., (...) Ora, esta situação modifica o status científico da Ciência do Direito, que deixa de se preocupar com a determinação daquilo que materialmente sempre foi Direito com o fito de descrever aquilo que, então, pode ser direito (relação causal), para ocupar-se com a oportunidade de certas decisões, tendo em vista aquilo que deve ser direito (relação imputação). Neste sentido, o seu problema não é propriamente uma questão de verdade, mas de decidibilidade. Os enunciados da Ciência do Direito que compõem as teorias jurídicas têm, por assim dizer, natureza criptonormativa, deles decorrendo conseqüências programáticas de decisões, pois devem prever, em todo caso, que, com sua ajuda, uma problemática social determinada seja solucionável sem exceções perturbadoras. (...) ..., os enunciados da Ciência Jurídica têm sua validade dependente de sua relevância prática. (...) Ao envolver uma questão de decidibilidade, a Ciência do Direito manifesta-se como pensamento tecnológico. Este possui algumas características do pensamento científico stricto sensu, à medida que parte das mesmas premissas que este. Os seus problemas, porém, têm uma relevância prática (possibilitar decisões: legislativas, judiciárias, administrativas, contratuais etc.) que exige uma interrupção na possibilidade de indagação das ciências em geral, no sentido de que a tecnologia dogmatiza os seus pontos de partida e problematiza apenas a sua aplicabilidade na solução de conflitos. (A ciência do Direito. São Paulo : Atlas, $1^{a}$ ed., 1977, p. 44-45). E, em complemento a essa visão da Ciência do Direito, ora sendo tomado como um sistema posto também na qualidade de instrumento de decidibilidade, 
Os avanços surgidos depois da nossa hodierna Constituição não podem ser ignorados pelo Direito, pois mudaram por completo o dia-a-dia da sociedade não apenas brasileira, mas mundial. Se na época de 1988 mal se tinha conhecimento do que era a rede mundial de computadores - guardada como bem estratégico-militar pelos norte-americanos desde meados do século XX durante a Guerra Fria (criada em 1969 com a designação de ARPANet) e internacionalmente designada pela expressão anglo-saxã internet -, hoje não se consegue mais sequer trabalhar sem ela.

Com isso, o preceito imunizador tem que ter sua exegese atualizada, evoluindo com os progressos da sociedade, de sorte a não se ter situações em que ele ora afete uma obra editada nos parâmetros tradicionais de publicação (ou seja, em papel) e, em outro momento, não alcance o mesmo teor armazenado em um CD-ROM, por exemplo; não será a embalagem usada, o formato ou o nome atribuído, a definir o objeto "livro", mas, sim, seu caráter essencial, o qual é que deve nortear a aplicação concreta da norma constitucional em crítica ${ }^{29}$.

tem-se que O sistema é um seletor de problemas. Se o problema não encontra solução no marco de um sistema (a), este tende a considerá-lo pura e simplesmente um falso problema e subseqüentemente descartá-lo (b). Mas o problema é um seletor de sistemas. Se ele não se resolve num determinado sistema (c), procura-se a solução noutro sistema (d). (...) Em conclusão: se um sistema estruturalista não o resolve, esse problema bem pode ser equacionado noutro sistema, o funcionalista. (BORGES, José Souto Maior. O contraditório no processo judicial (uma visão dialética). São Paulo : Malheiros Editores. 1996, p. 33 e 36).

29 Comenta Márcio Pestana que Interpretações que confiram estreiteza ao olhar constitucional devem ser reexaminados com a devida detenção e atenção. Dizer ser passivel de tributação insumos, como tintas, máquinas impressoras etc., é, a nosso ver, equivocadamente pretender conferir competência tributante a pessoas políticas de direito constitucional interno para tanto incompetentes, segundo o Texto Constitucional (O princípio da imunidade tributária. São Paulo: RT, 2001, p. 89), cuja linha de raciocínio bem se aplica aos discos, CD's, filmes etc. Idêntica orientação é a já supracitada doutrina de Aires Fernandino Barreto e Paulo Aires Barreto, para quem, inclusive, essa imunidade tributária, que configura-se $A m$ pla, irrestrita e incondicionada, há de merecer exegese lata e aberta (Imunidades tributárias: limitações constitucionais ao poder de tributar. São Paulo : Dialética, $2^{\mathrm{a}}$ ed., 2001, p. 86). Daí concluir-se que o apego à literalidade desse preceito prejudica o real dimensionamento almejado por qualquer norma ou princípio que preze pela sua plena eficácia e efetividade. 


\section{A JURISPRUDÊNCIA DO SUPREMO TRIBUNAL FEDERAL QUANTO À IMUNIDADE TRIBUTÁRIA SOBRE OS LIVROS ELETRÔNICOS}

Postos os fundamentos teóricos a embasarem as discussões sobre a jurisprudência, é de se mencionar que a merecedora de estudo mais detido, ante a alta influência que causa às Cortes Estaduais, além da real possibilidade de vinculação do entendimento destas ao seu (com base nas súmulas vinculantes), é a do Supremo Tribunal Federal.

Malgrado seu posicionamento hodierno tenha-se dado no sentido de que a imunidade tributária, tal qual posta no art. 150, VI, “d”, da Constituição Federal de 1988, quanto aos livros, jornais e periódicos, não abrange outros insumos que não os compreendidos na acepção da expressão "papel destinado a sua impressão”, a discussão está totalmente reaberta à luz de recente decisão dessa Excelsa Corte.

Em um dado caso concreto, uma primeira decisão monocrática deu provimento ao Recurso Extraordinário do Estado do Rio de Janeiro, afastando, com base na jurisprudência dominante da Corte, a imunidade sobre o ICMS fluminense quanto à comercialização da Enciclopédia Jurídica eletrônica por processamento de dados, com pertinência exclusiva ao seu conteúdo cultural software (sic); ocorre que, em uma segunda decisão monocrática por ocasião da oposição de embargos de declaração da parte vencida, restou determinada a suspensão do julgamento ${ }^{30}$ até que outra causa com possíveis reflexos, também em trâmite no Supremo Tribunal Federal, fosse decidida, pois nela reconhecida a a repercussão geral de matéria envolvendo o alcance da imunidade destinada aos livros, jornais e periódicos de que trata o referido dispositivo constitucional (sic) ${ }^{31}$.

30 RE 330.817/RJ; Rel. Ministro Dias Toffoli; j. em 04/02/2010; DJE de 05/03/2010; e j. 06/11/2010; DJE de 24/11/2010 (Disponível em: <http://www.stf.jus.br/portal/processo/verProcessoAndamento.asp?incidente $=1984213>$. Acesso em: 05/03/2011).

31 RE n 595.676/RJ; Rel. Ministro Marco Aurélio; Plenário Virtual; j. em 19/03/2010 (Disponível em:<http: //www.stf.jus.br/portal/processo/verProcessoAndamento. asp?incidente $=2651056>$. Acesso em: 05/03/2011. 
Dessa maneira, alguns pontos não explorados em julgamentos anteriores, poderão ser mais bem discutidos nessa nova oportunidade, maxime diante das atuais tecnologias a, v. g., disponibilizarem bibliotecas virtuais na rede mundial de computadores para serem armazenadas em componentes eletrônicos de facílimo manuseio e deslocamento (são os ditos Tablets).

$\mathrm{E}$, dentre os pontos a serem mais detidamente debatidos, como já dito anteriormente, certamente estarão as definições sobre os atrelamentos, ou não, da imunidade ao insumo "papel" destinado à impressão e, de conseguinte, sobre qual o formato que abarca para a veiculação das informações em livro sem tributação.

Há que se ponderar, quanto a isso, a respeito do conceito que se deve dar ao próprio "livro eletrônico", ou seja, se expressão tão-só vinculada ao dito CD-ROM ou igualmente ao hipertexto existente na rede mundial de computadores (dita internet), pois, nesta segunda hipótese, o conteúdo eletrônico não pode ser comercializado conjuntamente com o formato em papel, como um mero acessório sob um aspecto preponderantemente físico (a exemplo do que acontece com o CD-ROM), mas isoladamente ou enquanto uma autorização, uma "chave de acesso" ou senha que permite ao usuário do livro impresso não somente tê-lo eletronicamente, como atualizá-lo por certo período.

Além disso, nos dias de hoje, inclusive na área jurídica, já existem livros lidos e gravados, em bases eletrônicas que permitem reprodução audiovisual para serem ouvidos ou assistidos pelas pessoas (quando interpretados por atores - no caso de obras literárias -ou por professores - no caso dos cursos preparatórios para concursos) durante, $v$. g., seu tempo de deslocamento no tráfego de automóveis ou aviões, em escolas ou reuniões religiosas (no caso da Bíblia).

Se esses novos formatos tecnológicos de veiculação das mesmas informações havidas no livro impresso, conforme acima explicitado, podem ou não ser incluídos no conceito de 
"livro eletrônico", isso é dúvida ainda a ser dirimida pela jurisprudência contemporânea.

Outra dúvida a ser solucionada é se seu conteúdo deverá identicamente ser selecionado para receber a "benesse" tributária, a exemplo do que já se tem feito quanto às publicações que não encartam valores educacionais ou sociais desejáveis. De outro lado, é preciso ainda se refletir sobre o conteúdo existente em livro eletrônico, sem correspondência impressa em papel, ser imune ou não.

São circunstâncias como essas acima narradas que necessitam ser enfrentadas e solucionadas pela Suprema Corte constitucional brasileira, já que é ela que influencia e vincula o entendimento das demais Cortes pátrias, de modo a uniformizar sua jurisprudência, trazendo segurança e certeza a todos os envolvidos nos conflitos de interesses frente aos avanços tecnológicos da atualidade.

\section{CONCLUSÃO}

Conclui-se, portanto, que diante da inevitável tendência de se veicularem as informações contidas nos livros em formatos que cada vez mais evitem a edição em papel, justamente pela facilidade de acesso e armazenamento que as vias eletrônicas oferecem, podendo-se, e. g., carregar uma verdadeira biblioteca no bolso, com significativa economia de espaço e tempo de leitura (sempre escassos nos grandes centros urbanos), é mister que a jurisprudência pátria da Excelsa Corte reste revista para, seguindo a majoritária doutrina que já se verifica em harmonia com os avanços tecnológicos, entenda a imunidade constante do art. 150, VI, "d”, da Constituição de 1988, também abarcando a realidade dos livros eletrônicos, sob pena estar-se na contramão da histórica contemporânea.

Abstract: This article initially presents the problem of the difficulties of reconciling the tax immunity of the book between its two possibilities, the printed 
and electronic, as the biggest obstacle to be overcome by Constitutional and Tax Law. It then focuses on the directions of the current interpretative tax immunity on books, newspapers, periodicals and paper for your printer. It discusses the interpretation ebook, even in light of its jurisprudence. The article concludes by its full appropriateness.

Keywords: Tax immunity. Ebook. Interpretation.

\section{REFERÊNCIAS}

BARRETO, Aires Fernandino. "Limites da competência tributária municipal”. In: GASPARINI, Diogenes et alii. O Município e a constituinte: anais do XI encontro nacional de procuradores municipais. COSTA, Irany Gonçalves da (Coord.). Uberlândia : ABC-SABE, 1985, p. 87-95.

BARRETO, Aires Fernandino e BARRETO, Paulo Ayres. Imunidades tributárias: limitações constitucionais ao poder de tributar. São Paulo : Dialética, $1^{\text {a }}$ ed., 1999.

São Paulo : Dialética, 2a ed., 2001.

BORGES, José Souto Maior. "Isenções em tratados internacionais de impostos dos Estados-membros e Municípios”. In: LÓPEZ DÍAZ, Antonio et alii. Direito tributário: estudos em homenagem a Geraldo Ataliba. MELLO, Celso Antônio Bandeira de (Org.). São Paulo : Malheiros Editores, 1997, p. 166-178.

O contraditório no processo judicial (uma visão dialética). São Paulo : Malheiros Editores. 1996.

BRITO, Edvaldo. "O livro eletrônico é imune". In: BARRETO, Aires Fernandino et alii. Imunidade tributária do livro eletrônico. MACHADO, Hugo de Brito (Coord.). São Paulo : IOB Informações Objetivas, 1998, p. 33-49. São Paulo : Atlas, 2a ed., 2003, p. 35-54.

CALDAS, Roberto Correia da Silva Gomes. Imunidades tributárias. São Paulo, 2002, 144 p., Dissertação (Mestrado em Direito), Faculdade de Direito da Pontifícia Universidade Católica de São Paulo. 
_. "Breves considerações em torno da interpretação constitucional das normas de competência tributária (atributivas e desonerativas)". Interesse Público. Belo Horizonte : Editora Fórum, ano 11, n 57, set./out. 2009, p. 157-171.

CAMPOS, Dejalma de; CAMPOS, Marcelo. "A imunidade e as garantias constitucionais - alcance do artigo 150, VI, $d$, da CF”. In: BARRETO, Aires Fernandino et alii. Imunidade tributária do livro eletrônico. MACHADO, Hugo de Brito (Coord.). São Paulo : Atlas, 2a ed., 2003, p. 30-34.

CARRAZZA, Roque Antonio. "Livro eletrônico - imunidade tributária exegese do art. 150, VI, $d$, da Constituição Federal”. In: BARRETO, Aires Fernandino et alii. Imunidade tributária do livro eletrônico. MACHADO, Hugo de Brito (Coord.). São Paulo : Atlas, 2a ed., 2003, p. 254-272.

CASSONE, Vittorio. "Imunidade tributária do livro apresentado em CD-ROM ou disquete". In: BARRETO, Aires Fernandino et alii. Imunidade tributária do livro eletrônico. MACHADO, Hugo de Brito (Coord.). São Paulo : Atlas, 2a ed., 2003, p. 292-298.

COÊLHO, Sacha Calmon Navarro. Comentários à Constituição de 1998: sistema tributário. Rio de Janeiro : Forense, 8a edição, 1999.

. "A imunidade dos livros, jornais, periódicos e do papel destinado a sua impressão”. In: BARRETO, Aires Fernandino et alii. Imunidade tributária do livro eletrônico. MACHADO, Hugo de Brito (Coord.). São Paulo : Atlas, 2a ed., 2003, p. 273-281.

FERRAZ JR., Tércio Sampaio. FERRAZ JÚNIOR, Tércio Sampaio. A ciência do direito. São Paulo : Atlas, 1a ed., 1977.

GONÇALVES, José Artur Lima. "A imunidade tributária do livro". In: BARRETO, Aires Fernandino et alii. Imunidade tributária do livro eletrônico. MACHADO, Hugo de Brito (Coord.). São Paulo : Atlas, 2a ed., 2003, p. 139-163.

GRECO, Marco Aurelio. "Imunidade tributária do livro eletrônico". In: BARRETO, Aires Fernandino et alii. Imunidade tributária do livro eletrônico. MACHADO, Hugo de Brito (Coord.). São Paulo : Atlas, 2a ed., 2003, p. 164-176.

HARADA, Kiyoshi. "Imunidade tributária". In: MARTINS, Ives Gandra da Silva et alii. Imunidades tributárias. MARTINS, Ives Gandra da Silva 
(Coord.). São Paulo : co-edição Centro de Extensão Universitária e Revista dos Tribunais, 1998, p. 450-455.

LUNARDELLI, Pedro Guilherme Accorsi. "Imunidade sobre o livro eletrônico". In: BARRETO, Aires Fernandino et alii. Imunidade tributária do livro eletrônico. MACHADO, Hugo de Brito (Coord.). São Paulo : Atlas, 2a ed., 2003, p. 203-222.

MACHADO, Hugo de Brito; MACHADO SEGUNDO, Hugo de Brito. "Imunidade tributária do livro eletrônico". In: BARRETO, Aires Fernandino et alii. Imunidade tributária do livro eletrônico. MACHADO, Hugo de Brito (Coord.). São Paulo : Atlas, 2a ed., 2003, p. 97-120.

MACHADO, Schubert de Farias. "Imunidade do livro". In: BARRETO, Aires Fernandino et alii. Imunidade tributária do livro eletrônico. MACHADO, Hugo de Brito (Coord.). São Paulo : Atlas, 2a ed., 2003, p. 282-291.

MAIA FILHO, Napoleão Nunes. "A imunidade tributária dos livros e do papel destinado à sua impressão: (estudo tópico de exegese constitucional finalística)". In: BARRETO, Aires Fernandino et alii. Imunidade tributária do livro eletrônico. MACHADO, Hugo de Brito (Coord.). São Paulo : Atlas, 2a ed., 2003, p. 177-187.

MARTINS, Ives Gandra da Silva. "Imunidades tributárias". In: BARRETO, Aires Fernandino et alii. Imunidade tributária do livro eletrônico. MACHADO, Hugo de Brito (Coord.). São Paulo : Atlas, 2a ed., 2003, p. 121-129.

MORAES, Bernardo Ribeiro de. "A imunidade tributária e seus novos aspectos”. In: MARTINS, Ives Gandra da Silva et alii. Imunidades tributárias. MARTINS, Ives Gandra da Silva (Coord.). São Paulo : co-edição Centro de Extensão Universitária e Revista dos Tribunais, 1998, p. 105-142.

MOREIRA, Eduardo Ribeiro. "Conselhos constitucionais". Revista de direito constitucional e internacional: Cadernos de direito constitucional e ciência política. São Paulo : Editora Revista dos Tribunais, ano 18, n 71, abr./jun. 2010, p. 51-62.

NOGUEIRA, Johnson Barbosa. "A imunidade tributária do livro eletrônico". In: BARRETO, Aires Fernandino et alii. Imunidade tributária do livro eletrônico. MACHADO, Hugo de Brito (Coord.). São Paulo : Atlas, 2a ed., 2003, p. 130-138.

NOGUEIRA, Ruy Barbosa. Curso de direito tributário. São Paulo : Saraiva, 1995. 
OLIVEIRA, Felippe Daudt de. "O sentido da palavra livro no art. 150 da Constituição Federal - proteção da uma essência e não de um nome”. In: BARRETO, Aires Fernandino et alii. Imunidade tributária do livro eletrônico. MACHADO, Hugo de Brito (Coord.). São Paulo : Atlas, 2a ed., 2003, p. 68-78.

OLIVEIRA, Ricardo Mariz de. "O sentido e o alcance da imunidade constitucional para o livro". In: BARRETO, Aires Fernandino et alii. Imunidade tributária do livro eletrônico. MACHADO, Hugo de Brito (Coord.). São Paulo : Atlas, 2a ed., 2003, p. 239-253.

OLIVEIRA, Yonne Dolacio de. "A imunidade do art. 150, inciso VI, alínea $d$ da Constituição Federal, abrange ou não o denominado livro eletrônico?". In: BARRETO, Aires Fernandino et alii. Imunidade tributária do livro eletrônico. MACHADO, Hugo de Brito (Coord.). São Paulo : Atlas, 2a ed., 2003, p. 299-313.

PACHECO, Angela Maria da Motta. "Imunidade tributária do livro". In: BARRETO, Aires Fernandino et alii. Imunidade tributária do livro eletrônico. MACHADO, Hugo de Brito (Coord.). São Paulo : Atlas, 2a ed., 2003, p. 14-29.

PESTANA, Márcio. O princípio da imunidade tributária. São Paulo : RT, 2001.

Revista de Jurisprudência do Tribunal de Justiça do Estado de São Paulo RJTJESP. São Paulo : LEX, ano 18, vol. 87, 2 bim., mar/abr 1984.

Revista dos Tribunais: cadernos de direito constitucional e ciência política. São Paulo : Editora Revista dos Tribunais, ano 7, vol. 27, abr/jun 1999.

ROCHA, Valdir de Oliveira. "Imunidade tributária". In: MARTINS, Ives Gandra da Silva et alii. Imunidades tributárias. MARTINS, Ives Gandra da Silva (Coord.). São Paulo : co-edição Centro de Extensão Universitária e Revista dos Tribunais, 1998, p. 317-322.

SANTI, Eurico Marcos Diniz de. "Imunidade tributária como limite objetivo e as diferenças entre 'livro' e 'livro eletrônico'”. In: BARRETO, Aires Fernandino et alii. Imunidade tributária do livro eletrônico. MACHADO, Hugo de Brito (Coord.). São Paulo : Gráfica Editora ltda. (IOB Informações Objetivas), 1998, p. 51-62. . São Paulo : Atlas, 2a ed., 2003, p. 55-67. 
SARAIVA FILHO, Oswaldo Othon de Pontes. "Os CD-ROMs e disquetes com programas gravados são imunes?". Revista dialética de direito tributário. São Paulo : Dialética, no 7 , abr. 1996, p. 34-39.

"A não-extensão da imunidade aos chamados livros, jornais e periódicos eletrônicos”. Revista dialética de direito tributário. São Paulo : Dialética, no 33, jun. 1998, p. 133-141.

SUPREMO TRIBUNAL FEDERAL. Disponível em: <http://www.stf.jus. br/portal/inteiroTeor/pesquisar InteiroTeor.asp\#resultado>. Acesso em: 05/03/2011.

TÔRRES, Heleno Taveira; GARCIA,Vanessa Nobell. "Tributação e imunidade dos chamados 'livros eletrônicos"”. In: BARRETO, Aires Fernandino et alii. Imunidade tributária do livro eletrônico. Hugo de Brito Machado (Coord.). São Paulo : IOB Informações Objetivas, 1998, p. 73-86. São Paulo : Atlas, 2a ed., 2003, p. 79-96.

TORRES, Ricardo Lobo. "Imunidade tributária nos produtos de informática”. In: BARRETO, Aires Fernandino et alii. Imunidade tributária do livro eletrônico. MACHADO, Hugo de Brito (Coord.). São Paulo : Atlas, 2a ed., 2003, p. 223-238. 